\title{
Improved Diagnostic Techniques for Tomato Yellow Leaf Curl Virus in Tomato Breeding Programs
}

Belén Pico, Department of Biotechnology (Genetics), M. José Díez, Department of Biotechnology (Genetics), and Fernando Nuez, Department of Biotechnology (Genetics), Universidad Politécnica de Valencia, Camino de Vera 14, 46022, Valencia, Spain

\begin{abstract}
Pico, B., Díez, M. J., and Nuez, F. 1999. Improved diagnostic techniques for tomato yellow leaf curl virus in tomato breeding programs. Plant Dis. 83:1006-1012.

Breeding for tomatoes resistant to tomato yellow leaf curl geminivirus (TYLCV) is difficult, mainly due to the lack of an accurate system for selecting resistant plants. The variable nature of the genotypes used (wild or wild-derived genotypes and advanced breeding lines) makes the development of a reproducible selection procedure necessary during the breeding program. Serological and nucleic acid-based diagnostic techniques for detecting TYLCV were evaluated for their sensitivity, reliability, and possibility of quantification in order to select the combination of techniques that provides the most rapid and accurate characterization of the resistance level of each item. Squash blot followed by the more sensitive polymerase chain reaction (PCR) detection of inconclusive samples is recommended for the screening of new resistant sources among asymptomatic Lycopersicon spp., as they accumulate extremely low viral concentrations that cannot be detected by serological methods. A triple antibody sandwich-enzyme-linked immunosorbent assay (TAS-ELISA), modified to reduce the background, can be used in largescale field screening of advanced breeding lines if combined with the more sensitive squash blot, which is less affected by the age and state of the tissue. Hybridization methods were also more appropriate to assess viral distribution throughout the plant than TAS-ELISA or even PCR, which fails to reliably detect TYLCV in tissues like roots.
\end{abstract}

Additional keywords: Bemisia tabaci, Lycopersicon chilense, L. esculentum, L. peruvianum, screening for resistance, whitefly-transmitted geminivirus

Tomato yellow leaf curl geminivirus (TYLCV) is a whitefly-transmitted geminivirus that causes serious economic losses to tomato crops all over the world (26). Outbreaks of diseases caused by TYLCV and other closely related geminiviruses are being reported in new areas $(6,9,18)$ and affecting new crops (30). In Spain, TYLCV has mainly affected tomato crops, but recently it has also been detected in bean fields (22) and infecting new weed hosts (3).

Cultural practices adopted to control TYLCV epidemics must be combined with use of tolerant or resistant tomato varieties in severe open-air attacks $(17,27)$. Unfortunately, current breeding programs based on resistance found in wild Lycopersicon spp., mainly in L. chilense, are progressing slowly, partially due to the lack of effective means for accurate selection of resistant plants $(32,33)$. In other viral diseases affecting tomato, marker-assisted selection (MAS) provides a convenient and rapid

Corresponding author: Fernando Nuez

E-mail: fnuez@btc.upv.es

Accepted for publication 19 July 1999.

Publication no. D-1999-0913-01R

(C) 1999 The American Phytopathological Society assay for selection during breeding programs $(4,10)$, allowing the molecular detection of resistance genes. Restriction fragment length polymorphism (RFLP) and random amplified polymorphic DNA (RAPD) markers have been reportedly linked to the major gene of TYLCV resistance, $T y-1$, derived from $L$. chilense, and to a locus involved in quantitative resistance to TYLCV derived from $L$. pimpinellifolium $(5,20,36)$. However, the apparently complicated genetics of the character, i.e., the existence of minor modifying genes and the incomplete dominance and partial breakdown of resistance, still make MAS not feasible. Therefore, selection for TYLCV resistance depends on the phenotypic expression of TYLCV resistance genes.

The mild symptoms of TYLCV infection exhibited by wild tomato relatives and wild-derived material prevent accurate management of segregating populations and advanced breeding lines when selection is based solely on symptom severity (27,33). Therefore, sensitive, rapid, and reliable TYLCV detection methods are needed to accelerate the development of tomato cultivars resistant to TYLCV.

Several techniques have been used to detect TYLCV and assess its accumulation in host tissues. Immunoassays, i.e., triple antibody sandwich-enzyme-linked im- munosorbent assay (TAS-ELISA) and tissue-blot immunoassay (TBIA), employed in the diagnosis of other virus diseases have limitations to the specific detection of geminiviruses due to crossreaction caused by the high homology among their coat proteins (31). This limitation has been used as an advantage to detect TYLCV by using heterologous antisera $(2,14,19)$. Antisera against TYLCV have recently become available commercially (15).

Sequence analysis of different TYLCV isolates has resulted in three homology groups: TYLCV-Tha (Thailand), TYLCVIsr (Israel), and TYLCV-Sar (Sardinia) (26). This has allowed the development of nucleic acid probes for squash, dot, and southern blotting hybridization $(7,8,23,29,37)$ and the design of degenerate or specific primers for broad-range or for specific polymerase chain reaction (PCR)-based detection methods $(12,21,24,34)$.

Use of different detection techniques may lead to noncomparable and contradictory results, making the progress of breeding programs difficult. Therefore, an appropriate combination of detection techniques is needed to better characterize resistance found in different genotypes, optimizing the selection process.

In this study, we evaluated the use of different detection techniques, e.g., serological methods (TAS-ELISA, squash, and dot immunoblotting) and nucleic acidbased techniques (squash blot, dot blot, and PCR), to search for new wild sources of TYLCV resistance, to screen wild-derived genotypes with different degrees of resistance, for field screening of advanced breeding lines, and for monitoring viral accumulation in different plant tissues, which is necessary for a better understanding of resistance mechanisms.

\section{MATERIALS AND METHODS}

Plant materials. Plant materials from different steps in a breeding program were used. Accessions of $L$. peruvianum and $L$. chilense were used in the screening of new wild resistance sources: L. peruvianum PI126935 and PI-143679 are both asymptomatic carriers of TYLCV-Sar (27). The former has also been used in Israel as a resistance source against TYLCV-Isr to produce commercial tomato hybrids (28). These accessions were supplied by the Plant Introduction Station, USDA, Ames, 
Iowa. L. chilense LA 2884 and LA 1932 have different levels of resistance to TYLCV-Sar (27); and L. chilense LA1969, which is the carrier of the TYLCV resistance gene $T y-1$ used in current breeding programs $(20,35)$, was supplied by C. M. Rick, Tomato Genetics Resource Center, University of California, Davis.

Wild-derived materials were also employed: an interspecific hybrid obtained from the cross $L$. esculentum $\times L$. peruvianum PI-143679 (F1-per) by using pollen mixture and embryo culture techniques, and a second backcross to tomato derived from the cross $L$. esculentum $\times L$. chilense LA 1938 (BC2-chil).

In field screening, advanced tomato breeding lines derived from $L$. chilense LA 1932 and LA 1938 (5 $5^{\circ} 8^{\circ}$ backcross $)$ were also used.

In interspecific crosses, the tomato line FC, carrier of the recessive marker gene $c$ (potato leaf), was used as a female parent. This line was also used as a TYLCV-susceptible control in all assays.

Whitefly maintenance and virus source. Bemisia tabaci colonies were reared on healthy plants of the tomato line FC. These plants were grown in muslincovered cages. An isolate of TYLCV belonging to the TYLCV-Sar group was obtained from tomato plants from Murcia (a tomato producing region in southern Spain) and maintained in plants of the tomato line FC by whitefly transmission, renewing the virus stock every month.

Inoculation procedures. Two artificial whitefly-mediated inoculation methods, cage and mass inoculation, were used to inoculate wild and wild-derived genotypes, essentially as described in Pico et al. (27).

Cage inoculation. B. tabaci adults were given a 48-h acquisition access period on TYLCV-infected tomato source plants. Whiteflies were then moved to fourth-leafstage seedlings of each genotype grown in trays $(25 \times 15 \mathrm{~cm})$ that were individually exposed to 15 to 25 viruliferous whiteflies per plant for 4 days in whitefly-protected cages. After inoculation, plants were sprayed with imidacloprid (Confidor) and held in an insect-proof greenhouse for symptom development and sampling.

Mass inoculation. Plants of different genotypes were grown in pots in meshprotected greenhouses. L. esculentum plants showing severe TYLCV symptoms and maintaining a high population of $B$. tabaci were used as an inoculum source (one infected source plant per five tested plants). Plants were periodically agitated to obtain a uniform vector distribution. No chemicals were applied during the assays.

Natural infection. Natural infection was monitored in advanced tomato breeding lines derived from $L$. chilense in summerautumn growing cycles in commercial fields in Murcia (southern Spain).

Symptom monitoring and sampling. Symptom severity was assessed for each plant and graded on a scale of 0 (symptomless) to 4 (severe symptoms). In all cases, individual plants were tested for the presence of TYLCV virions and/or viral DNA on different days postinoculation (DPI). To evaluate different diagnostic techniques, three sets of samples were collected from each tissue per plant. One set of samples was used for serological assays, a second was squashed onto nitrocellulose or nylon membranes for serological and/or nucleic acid-based detection, and the other was extracted for dot blot and PCR analyses.

Serological assays. For TYLCV detection, commercial polyclonal and monoclonal antisera against TYLCV (ADGEN Diagnostic Systems, Scotland) were used. Serological techniques, including TASELISA, and squash and dot immunoassays (TBIA) were tested for the detection of TYLCV.

TAS-ELISA. Two TAS-ELISA procedures were used. (i) Standard TAS-ELISA (S-TAS): This procedure was conducted essentially as reported in Pico et al. (27). Polyclonal antiserum against TYLCV was diluted 1:1,000 in carbonate buffer $(\mathrm{pH}$ 9.6) to coat wells in standard 98-well microtiter plates and incubated for $2 \mathrm{~h}$ at $34^{\circ} \mathrm{C}$. Tissue from infected plants and healthy controls was extracted in 1:10 (wt/vol) extraction buffer as described by Macintosh et al. (19). Monoclonal antiserum was used diluted 1:1,000 in phosphate buffered saline (PBS), and rabbit antimouse globulin/alkaline phosphatase conjugate was diluted 1:1,500 in PBS. Absorbances $\left(A_{405} \mathrm{~nm}\right)$ after overnight incubation at $4{ }^{\circ} \mathrm{C}$ with substrate ( $p$-nitrophenyl phosphate) were scored as follows: 0 ( $\leq$ twice that of the healthy control); 1 (>twice that of the healthy control but $\leq 0.6) ; 2(>0.6$ but $\leq 1.2)$; 3 (>1.2 but $\leq 1.8) ; 4$ (>1.8) (19).

(ii) Modified TAS-ELISA (M-TAS): The previous procedure was modified by blocking the plates with PBS $+4 \%$ BSA (bovine serum albumin) for $1 \mathrm{~h}$ after polyclonal coating, and by adding $1 \%$ BSA to the extraction buffer, the monoclonal antiserum buffer, and the globulin/alkaline phosphatase conjugate buffer (kindly suggested by I. Hita, CIDA-Murcia, Spain).

Immunoblotting. For squash immunoassays, $0.5 \mathrm{~cm}$ of stem, leaf, and root sections were cut and pressed onto a nitrocellulose membrane. For dot immunoassays, 5 $\mu \mathrm{l}$ of crude extract prepared as for TASELISA was spotted onto membrane. Single whiteflies reared on infected plants of the tomato line FC were directly squashed onto the membrane.

The technique described by Abou Jawdah et al. (2) was followed with minor modifications. Nitrocellulose membranes were treated for $1 \mathrm{~h}$ with blocking buffer (Tris buffered saline (TBS), $\mathrm{pH} \mathrm{7.4,} \mathrm{con-}$ taining $2 \%$ gelatin and $2 \%$ Triton). After blocking, membranes were incubated with monoclonal antiserum (ADGEN) diluted
$1: 1,000$ in TBS $+0.1 \%$ BSA for $1 \mathrm{~h}$ followed by rabbit anti-mouse globulin/alkaline phosphatase conjugate diluted $1: 1,000$ in TBS $+0.1 \%$ BSA for $1 \mathrm{~h}$. Finally, the blots were incubated for 10 to 15 min in the substrate solution. TYLCV was detected in tissue blots by the formation of a black-purple precipitate.

Nucleic acid-based assays. Viral DNA was detected by squash and dot blotting. For squash blotting, sections of $0.5 \mathrm{~cm}$ of different plant tissues were directly squashed onto a nylon membrane. Single whiteflies were spotted onto membranes as described for immunoblotting.

Total nucleic acids and sap extracts were obtained for dot blots from both infected plants and healthy controls according to the following four extraction procedures. In all cases, plant tissue was frozen in liquid nitrogen and ground into a fine powder.

Total nucleic acids extracts.

(i) Extraction procedure 1 (EP1) (8): Frozen tissue was crushed in boiling extraction buffer (2\% CTAB, $100 \mathrm{mM}$ Tris$\mathrm{HCl}$ [pH 8], $10 \mathrm{mM}$ EDTA, $1.4 \mathrm{M} \mathrm{NaCl}$, $1 \%$ 2- $\beta$-mercaptoethanol) and incubated for $5 \mathrm{~min}$ at $55^{\circ} \mathrm{C}$. Supernatants were extracted after washing with 1 vol of phenol:chloroform:isoamyl 25:24:1. Total nucleic acids were recovered by precipitation with absolute ethanol. The pellets were washed with 70 and 100\% ethanol, dried, and resuspended in TE buffer (10 $\mathrm{mM}$ Tris- $\mathrm{HCl}$ and $1 \mathrm{mM}$ EDTA [pH 7.5]).

(ii) Extraction procedure 2 (EP2) (modified from Dellaporta et al. [11] according to Crespi et al. [7]): Frozen tissue was crushed in extraction buffer $(100 \mathrm{mM}$ Tris- $\mathrm{HCl}[\mathrm{pH} 8], 50 \mathrm{mM}$ EDTA, $500 \mathrm{mM}$ $\mathrm{NaCl}, 10 \mathrm{mM}$ 2- $\beta$-mercaptoethanol, and $1 \%$ sodium dodecyl sulfate [SDS]) and incubated at $65^{\circ} \mathrm{C}$ for $5 \mathrm{~min}$. Then $0.25 \mathrm{vol}$ of $5 \mathrm{M}$ potassium acetate $(\mathrm{pH} 4.8)$ was added and samples were incubated on ice for $10 \mathrm{~min}$. After centrifugation for 10 min, supernatants were precipitated with isopropanol and processed as in EP1.

\section{Sap extracts.}

(iii) Extraction procedure 3 (EP3) (15): Frozen tissue was crushed in extraction buffer (50 mM Tris-HCl, 1 mM EDTA [pH $8]$ ), and 1 vol of $1 \mathrm{M} \mathrm{NaOH}$ was then added. Supernatants were recovered after incubation at room temperature for $30 \mathrm{~min}$ and 10 min centrifugation.

(iv) Extraction procedure 4 (EP4) (modified from Rom et al. [29]): Frozen tissue was crushed in $0.4 \mathrm{M} \mathrm{NaOH}$. Supernatants were recovered after 2 min centrifugation.

Five $\mu 1$ of each sample corresponding to about $5 \mathrm{mg}$ of fresh tissue and serial aliquots were spotted onto nylon membranes for dot blot hybridization.

Hybridization. Both dot and squash samples blotted on membranes were UVcrosslinked and overnight hybridized at $65^{\circ} \mathrm{C}$ with TYLCV-DNA probe at approximately $10 \mathrm{ng} / \mathrm{ml}$ in buffer containing 
phosphate buffer (pH 7.2), 1 mM EDTA, and $7 \%$ SDS and washed once in $2 \times$ SSC$2 \%$ SDS (10 $\mathrm{min})$ at room temperature, and then twice in $0.1 \times$ SSC- $0.1 \%$ SDS (15 $\min )$ at $60^{\circ} \mathrm{C}$. The probe routinely employed (kindly provided by E. R. Bejarano, Universidad de Málaga, Spain) represented the entire genome $(2.77 \mathrm{~kb})$ of a Spanish TYLCV isolate (TYLCV-Alm) belonging to the TYLCV-Sar group, and was ${ }^{32} \mathrm{P}-$ dCTP radiolabeled by random-priming. After hybridization, membranes were exposed to a phosphorimager screen (Bioimaging analyzer, BAS-1500, Fujifilm, Tokyo). The amount of viral ssDNA in each dot was quantified according to a standard curve of TYLCV DNA (ranging from $10 \mathrm{ng}$ to $1 \mathrm{pg}$ ) dotted on the same membrane. Densitometric squash blotting results were scored from 0 (no reaction) to 4 (strong reaction $=$ reaction of the susceptible control).

PCR. The two primers were designed based on a common sequence of TYLCVSar and TYLCV-Isr (sense 5'-CGC CCG TCT CGA AGG TTC-3' and antisense 5'GCC ATA TAC AAT AAC AAG GC-3') (kindly supplied by J. L. Cenis, CIDA, Murcia, Spain). Five $\mu$ l of each sample was used in a total volume of $25 \mu$ in the following PCR mixture: $2.5 \mu \mathrm{l}$ of $10 \mathrm{mM}$ of each primer, $2 \mu \mathrm{l}$ of $2.5 \mathrm{mM}$ of each dNTP, $1.5 \mu \mathrm{l}$ of $25 \mathrm{mM} \mathrm{MgCl} 2,2.5 \mu \mathrm{l}$ of $10 \times \mathrm{Taq}$ buffer, and 2 units of Taq DNA polymerase (Boehringer Mannheim, GmbH, Germany). The cycling profile was $10 \mathrm{~min}$ of melting at $95^{\circ} \mathrm{C}$ followed by 35 cycles of melting, annealing, and DNA extension of $1 \mathrm{~min}$ at $95^{\circ} \mathrm{C}, 30 \mathrm{~s}$ at $53^{\circ} \mathrm{C}$, and $2 \mathrm{~min}$ at $72^{\circ} \mathrm{C}$, respectively. The predicted length of the amplified fragment is approximately 670 bp. PCR products were electrophoresed in $1 \%$ agarose gels and photographed after ethidium bromide staining.

Comparison of sensitivity. Crude MTAS-ELISA extracts of susceptible and partially resistant genotypes were serially diluted to evaluate the sensitivity of this serological method. Serial dilutions of EP2 extracts derived from susceptible and partially resistant materials were used for comparison of sensitivity of hybridization and PCR detection methods.
Statistical analysis. Statistical analyses were carried out by means of both one-way and multifactor analysis of variance, and by a Newman-Keuls multiple range test for mean comparisons (Statgraphics Plus, Statistical Graphics Corp.).

\section{RESULTS}

TYLCV detection by serological methods. TYLCV was detected using polyclonal and monoclonal antisera by the three serological procedures, TAS-ELISA, squash, and dot immunoblotting, in susceptible controls. Two TAS-ELISA procedures, S-TAS and M-TAS, were used. Analysis of variance indicated significant differences in the readings of healthy controls with both procedures (Table 1). The mean background value was higher when using S-TAS-ELISA than that obtained with M-TAS-ELISA.

S-TAS-ELISA values were erratic, with false negatives in susceptible genotypes (FC) showing clear TYLCV symptoms and unexpectedly high readings in some samples from highly resistant genotypes ( $L$. chilense LA 1932) in which a reduced viral accumulation would be expected (27). MTAS-ELISA allowed for a more effective differentiation among susceptible geno- types, positives, and highly resistant materials, negatives. The most discriminatory results were obtained with samples derived from apex tissues, where viral accumulation is expected to be higher. Due to the reduced background and the consistency of the results, M-TAS-ELISA was selected for the latter assays.

Comparison of TAS-ELISA and immunoblotting. M-TAS-ELISA was successfully employed to study the pattern of TYLCV distribution in susceptible genotypes (FC) (Fig. 1), whereas both squash and dot immunoblotting detected TYLCV only in tissues in which viral accumulation was significantly higher (apex and higher stem sections). The weak signals obtained in the other tissues were masked by a high background, also found in healthy controls, probably caused by poor blocking of the membrane. Neither procedure, M-TASELISA or immunoblotting, was found suitable to accurately study the pattern of TYLCV distribution in the partially resistant L. peruvianum PI-126935.

TYLCV detection by nucleic acidbased assays. Viral TYLCV ssDNA was successfully detected in direct squashes of tissues and in sap or nucleic acid extracts by using the described TYLCV-Sar probe.

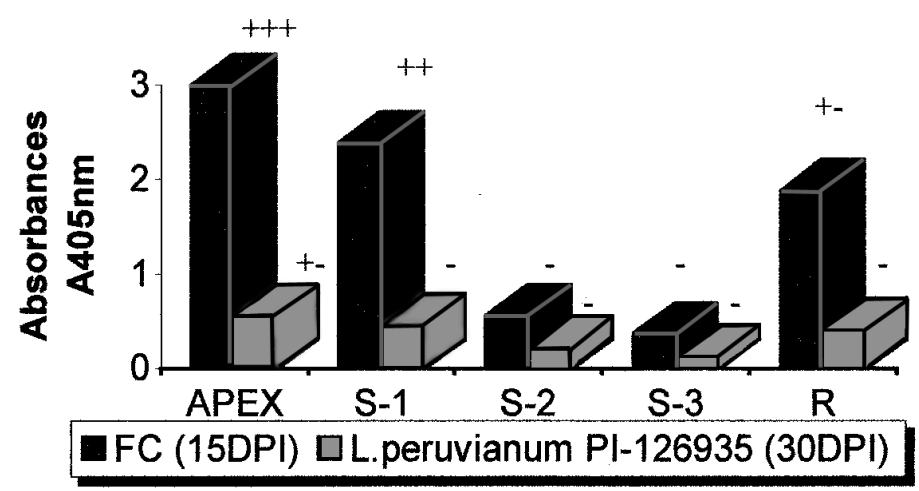

Fig. 1. Detection of tomato yellow leaf curl geminivirus (TYLCV) by modified triple antibody sandwich-enzyme-linked immunosorbent assay (M-TAS-ELISA) and tissue immunoblotting in samples of different plant tissues from susceptible tomato and a partially resistant wild genotype. DPI: Days post cage whitefly-mediated inoculation. Absorbances $\left(A_{405 \mathrm{~nm}}\right)$ were recorded $24 \mathrm{~h}$ after addition of substrate and represent averages of four wells. APEX: Shoot apex. S-1: Stem section at the apex region. S-2: Stem section in middle of plant. S-3: Basal stem section. R: Roots. (+) represents visual rating of both squash and dot immunoblotting. (+-) indicates inconclusive diagnosis due to high background.

Table 1. Tomato yellow leaf curl virus (TYLCV) detection by using standard and modified triple antibody sandwich-enzyme-linked immunosorbent assays (S- and M-TAS-ELISA) in susceptible tomato and a highly resistant Lycopersicon chilense accession

\begin{tabular}{|c|c|c|c|c|c|}
\hline \multirow[b]{2}{*}{ Genotype } & \multicolumn{2}{|c|}{ Young leaf tissue } & \multicolumn{2}{|c|}{ Shoot apex tissue } & \multirow[b]{2}{*}{ Symptoms $^{b}$} \\
\hline & S-TAS ${ }^{\mathbf{a}}$ & M-TAS & S-TAS & M-TAS & \\
\hline L. esculentum $\mathrm{FC}(30 \mathrm{DPI})^{\mathrm{c}}$ & 0.5 & 1.25 & 1.5 & 2.75 & 4 \\
\hline L. esculentum FC (10 DPI) & 1.5 & 0.75 & 1 & 1.25 & 1 \\
\hline L. chilense LA 1932 (30 DPI) & 0.75 & 0.25 & 2.25 & 0.25 & 0 \\
\hline \multirow[t]{2}{*}{ Healthy control-L. esculentum FC } & $0.257 \pm 0.113^{\mathrm{d}}$ & $0.098 \pm 0.0254^{\mathrm{d}}$ & $0.211 \pm 0.0474^{\mathrm{d}}$ & $0.07 \pm 0.0175^{\mathrm{d}}$ & 0 \\
\hline & \multicolumn{2}{|c|}{$P=0.0340$} & \multicolumn{2}{|c|}{$P=0.014$} & \\
\hline
\end{tabular}

a Absorbances were taken $24 \mathrm{~h}$ after addition of substrate and represent means of four wells. Numbers indicate ELISA readings $\left(A_{405} \mathrm{~nm}\right)$ score as follows: negative $=0$ ( $\leq$ twice the absorbance on the healthy control); 1 ( $>$ twice the healthy control but $\leq 0.6) ; 2(>0.6$ but $\leq 1.2) ; 3(>1.2$ but $\leq 1.8) ; 4(>1.8)$.

${ }^{\mathrm{b}}$ Mean scores of symptoms for each genotype: 0 (symptomless) to 4 (severe symptoms).

${ }^{c}$ DPI: days post cage whitefly-mediated inoculation.

d Analysis of variance (ANOVA) results: Mean, standard deviation, and $P$ values for significant differences between S-TAS-ELISA and M-TAS-ELISA readings. 
The detection limit, 1 to $5 \mathrm{pg}$, was estimated by using a calibration curve constructed with samples of known concentration of purified TYLCV DNA. Similar sensitivity was obtained for both dot blot and squash blot procedures. Hybridization with healthy controls was not observed in any case.

Extraction procedures. The four extraction procedures allowed us to distinguish between susceptible and partially resistant genotypes (Table 2). The relative order of the different genotypes based on the level of viral accumulation was consistent using the four EP, and was positively correlated with symptomatology for the most susceptible (FC) and the most resistant genotypes ( $L$. peruvianum PI126935 and L. chilense LA 1932). However, differences in ssDNA accumulation were not directly correlated with symptom severity in wild-derived materials with intermediate levels of resistance (F1-per and BC2-chil).

The analysis of variance indicated significant differences in the concentration of TYLCV ssDNA extracted by the four methods in each genotype (Table 2). EP2, EP3, and EP4 were effective for extraction of detectable TYLCV DNA in spots corresponding to as little as $5 \mu \mathrm{g}$ of plant tissue from susceptible FC, 10 to $20 \mu \mathrm{g}$ of plant tissue from moderately resistant materials (F1-per and BC2-chil), and $0.1 \mathrm{mg}$ of plant tissue in partially resistant wild sources ( $L$. peruvianum PI-126935). The amount of viral ssDNA obtained by the EP1 procedure was 2 to 20 times lower than that obtained with the other EP, probably because of DNA losses during the purification procedure. Thus, EP1 did not yield detectable amounts of viral DNA from less than $1 \mathrm{mg}$ of tissue in the partially resistant
L. peruvianum PI-126935. Viral DNA was only barely detected in some single samples of EP2, EP3, and EP4 from extracts corresponding to $5 \mathrm{mg}$ of plant tissue of $L$. chilense LA 1932.

TYLCV detection by PCR. Since dot blotting failed to consistently detect TYLCV in highly resistant genotypes, the four EP extracts were used as templates for PCR amplification. Only EP1 and EP2 yielded DNA of quality to be directly used in PCR (Table 2). Only erratic amplifications (+-) were obtained with the fast sap extraction procedures EP3 and EP4, even after serial dilutions, probably due to the existence of sap contaminants that may inhibit Taq DNA polymerase amplification. These extracts should be purified with resins or columns before their use for PCR amplification. EP2 was selected for further assays as being more effective than EP1 in extracting high-quality TYLCV DNA.

Comparison of sensitivity of serological and nucleic acid-based methods. The sensitivity of M-TAS-ELISA and PCR was compared with that of the hybridization methods by quantifying the ssDNA concentration in each EP2 sample by dot blot according to the calibration curve constructed with known amounts of purified TYLCV DNA (Table 3). Using this reference, M-TAS-ELISA was estimated to detect TYLCV in samples with viral concentration of $>100 \mathrm{pg}$ of viral ssDNA. PCR was, as expected, more sensitive than hybridization methods, detecting TYLCV in samples with less than $1 \mathrm{pg}$ of ssDNA, that is, in less than $1 \mu \mathrm{g}$ and $0.1 \mathrm{mg}$ of fresh tissue from susceptible and highly resistant material, respectively.

TYLCV detection in whiteflies. The two membrane methods (squash immuno- blotting and squash blotting) were successfully used for rapid and reliable detection of TYLCV and TYLCV-ssDNA, respectively, in squash blots of individual virus-carrier whiteflies. Both methods were equally effective in detecting the first viruliferous adults in a healthy whitefly population reared on infected FC tomato plants before the appearance of symptoms. Therefore, both could be used to score inoculum pressure in whitefly population in field conditions.

Screening for new wild resistance sources. M-TAS-ELISA, squash blotting, and PCR were compared to search for new resistant Lycopersicon spp. sources. TYLCV detection percentages, compared with the total plants inoculated, were lower with M-TAS-ELISA (10 to 40\%) than with squash blot or PCR (20 to 100\%) (Table 4). The latter allowed a more accurate differentiation among resistance levels of different Lycopersicon spp., placing them into two groups. The first group includes the accessions L. peruvianum PI-126935 and PI-143679, and L. chilense LA 2884, which are asymptomatic TYLCV carriers exhibiting high percentages of infected plants (>85\%). Although PCR is more sensitive than squash blot, the latter allows for a rough quantification of viral DNA accumulation (VA) that successfully differentiates between the resistance levels of the two accessions of $L$. peruvianum $(\mathrm{VA}=1.4$ in PI $143679>\mathrm{VA}=0.8$ in PI 126935) with similar infection percentages. The second group includes the accessions $L$. chilense LA 1932 and LA 1969, with lower percentages of infection $(<30 \%)$ and reduced virus content (VA $<0.2$ in both cases).

Field assaying of advancing tomato breeding lines. The three diagnostic tech-

Table 2. Detectable tomato yellow leaf curl virus (TYLCV) ssDNA by hybridization with a radiolabeled probe and polymerase chain reaction (PCR) in samples from fresh shoot apex tissues using four extraction procedures

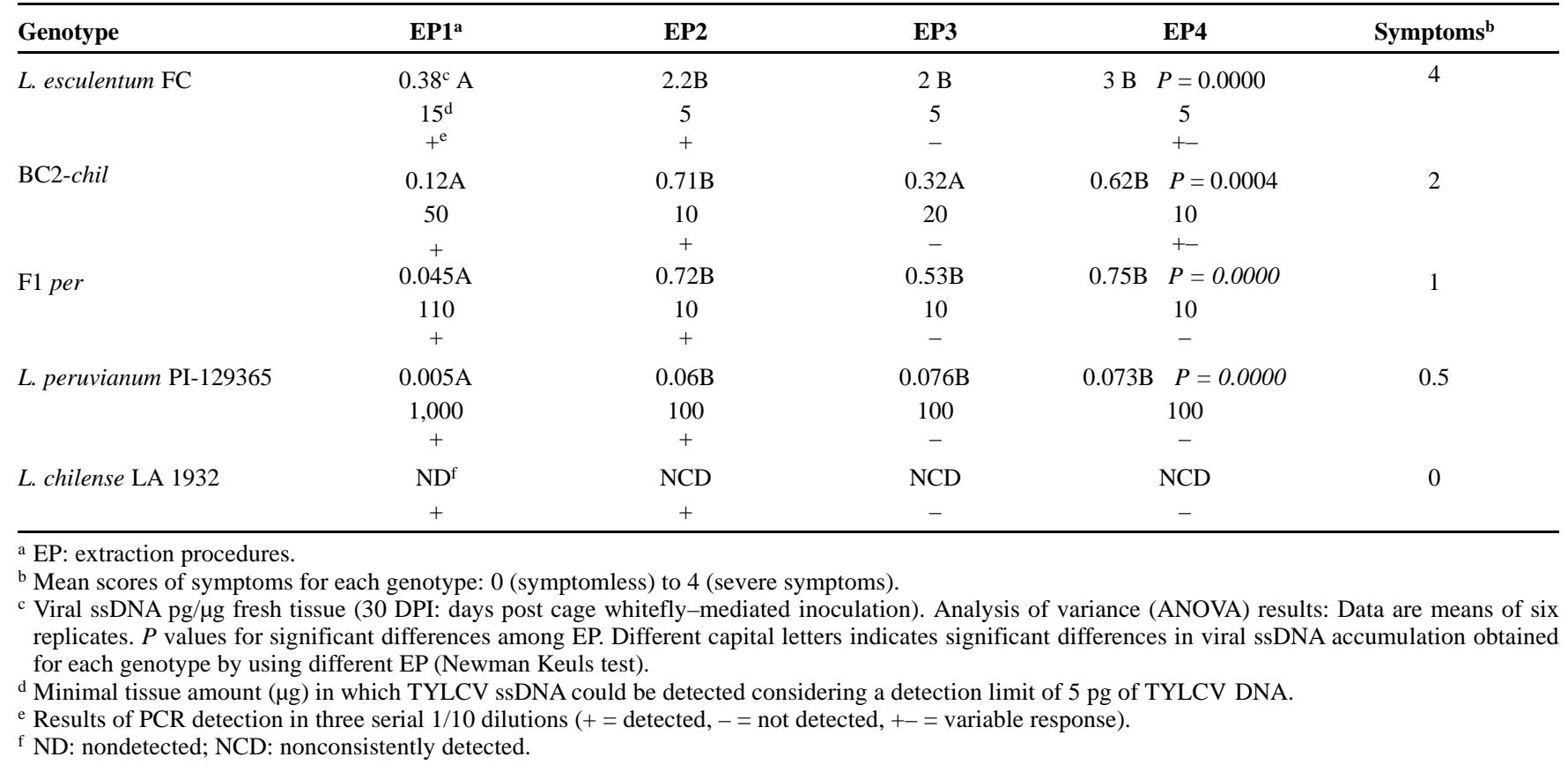


niques were also used for large-scale detection of TYLCV in advanced breeding lines grown in commercial fields in Murcia (southern Spain). Initial sampling by using TAS-ELISA allowed identification of a high number of positives. However, a high number of misleading results was also obtained, mainly in plants with slight symptoms or in plants suspected to be infected with other viruses such as TSWV or ToMV. Sixty-three percent of the MTAS-ELISA misleading samples were clearly positive with molecular hybridization, while only $40 \%$ were positive by PCR, probably due to the advanced developmental stage of plants that yield extracts with high levels of contaminants.

Selecting the appropriate tissue and time of sampling. TYLCV accumulates mainly in dividing tissues, i.e., apex and roots after inoculation. The time at which viral accumulation begins and the accumulation level could be reliable indicators of resistance. Therefore, we compared the reliability of M-TAS-ELISA, molecular hybridization, and PCR in detecting and quantifying TYLCV in different plant tissues, shoot apex and roots, at different DPI in susceptible (FC) and partially resistant material (BC2-chil) (Fig. 2).

The earliest detection (4 DPI) was by PCR in shoot apex tissues, reaching $100 \%$ detection after a week in both FC and BC2-chil. The effectiveness of PCR detection decreased in advanced states of infection (30 DPI), when plants exhibited severe symptoms and the level of contaminants increased the erratic results. This could also explain the low percentages of PCR detection when using root samples.

Hybridization procedures were more effective than PCR in distinguishing between susceptible and partially resistant material. Both squash and dot blotting detected
DNA in shoots and roots from 4 and 8 DPI on. The greatest differences among genotypes were found at 12 to $16 \mathrm{DPI}$.

A high correlation was found with $\mathrm{M}$ TAS-ELISA and squash blot with the symptomatology in shoot apex samples in both genotypes (Fig. 2). However, M-TASELISA failed to reliably detect TYLCV in early and late stages of infection, resulting in a high number of inconclusive results. M-TAS-ELISA gave unexpectedly high values in roots samples, which do not allow accurate infection monitoring and do not differentiate between the resistance levels of FC and BC2-chil as accurately as squash blot.

\section{DISCUSSION}

Breeding programs aimed at developing tomato cultivars resistant to TYLCV have progressed slowly, mainly due to the heterogeneous conditions in which they are conducted, i.e., the variability among TYLCV isolates and/or B. tabaci biotypes, the use of different inoculation techniques, and especially the lack of an accurate sys- tem for selection during the breeding process.

Although the last evaluation of the level of resistance must correspond to the effect of infection on total yield and yield components (17), during the breeding program, the percentage of infected plants and the level of viral accumulation can serve as indicators of resistance. A combination of serological and nucleic acid-based detection methods can be successfully used to characterize the level of resistance of genotypes.

M-TAS-ELISA allows for an accurate differentiation between highly susceptible and highly resistant genotypes. Similar results were found with serological techniques in other studies using other heterologous antisera $(2,13,16,25)$. However, the low sensitivity of TAS-ELISA precludes this technique from differentiating degrees of resistance found in wild accessions with low levels of viral accumulation (L. peruvianum and L. chilense). Although this method possesses the ideal properties for use in large-scale analysis, we have

Table 4. Comparative effectiveness of serological and nucleic acid-based tomato yellow leaf curl virus (TYLCV) detection techniques in screening for new wild resistance sources

\begin{tabular}{|c|c|c|c|c|}
\hline Accession & M-TAS-ELISA ${ }^{\mathrm{a}}(\%)$ & Squash blot (\%) & $\operatorname{PCR}(\%)$ & $\mathbf{V A}^{\mathbf{b}}$ \\
\hline \multicolumn{5}{|c|}{ Lycopersicon peruvianum } \\
\hline PI-143679 & $33^{\mathrm{c}}$ & $88^{c}$ & $90^{\mathrm{c}}$ & 1.4 \\
\hline PI-126935 & 40 & 85 & 90 & 0.8 \\
\hline \multicolumn{5}{|l|}{ L. chilense } \\
\hline LA 2884 & 35 & 90 & 100 & 1.5 \\
\hline LA 1932 & 15 & 30 & 20 & 0.15 \\
\hline LA 1969 & 10 & 20 & 20 & 0.2 \\
\hline
\end{tabular}

a Modified triple antibody sandwich-enzyme-linked immunosorbent assay.

${ }^{b}$ VA: Viral accumulation as estimated by scoring densitometric squash blot results ranging from 0 (no signal) to 4 (strong signal of the susceptible control).

${ }^{c}$ Percentage of samples in which TYLCV was detected (60 DPI) with each technique (based on the total number of plants inoculated).

Table 3. Comparative sensitivity of modified triple antibody sandwich-enzyme-linked immunosorbent assay (M-TAS-ELISA), dot hybridization, and polymerase chain reaction (PCR) for tomato yellow leaf curl virus (TYLCV) detection

\begin{tabular}{|c|c|c|c|c|c|c|c|}
\hline \multirow{3}{*}{$\begin{array}{l}\text { Genotype } \\
\text { Diagnostic technique }\end{array}$} & \multicolumn{7}{|c|}{ Fresh tissue weight ${ }^{a}$} \\
\hline & $\mathrm{EP} 2=5 \mathrm{mg}$ & D1 = $1 \mathrm{mg}$ & $\mathrm{D} 2=100 \mu \mathrm{g}$ & $\mathrm{D3}=10 \mu \mathrm{g}$ & D4 = $1 \mu \mathrm{g}$ & D5 = $100 \mathrm{ng}$ & D6 $=10 \mathrm{ng}$ \\
\hline & \multicolumn{7}{|c|}{ Viral ssDNA $^{\mathbf{b}}$} \\
\hline Lycopersicon esculentum FC & $10 \mathrm{ng}$ & $2 \mathrm{ng}^{\mathrm{c}}$ & $200 \mathrm{pg}$ & $20 \mathrm{pg}$ & $2 \mathrm{pg}$ & $0.2 \mathrm{pg}$ & $0.02 \mathrm{pg}$ \\
\hline PCR & $-\mathrm{d}$ & - & + & + & + & + & +- \\
\hline Dot blot & + & + & + & +- & - & & \\
\hline ELISA & + & + & +- & - & & & \\
\hline L. peruvianum PI-126935 & $250 \mathrm{pg}$ & $50 \mathrm{pg}$ & $5 \mathrm{pg}$ & $0.5 \mathrm{pg}$ & & & \\
\hline PCR & - & + & + & +- & & & \\
\hline Dot blot & + & +- & - & & & & \\
\hline ELISA & +- & - & - & & & & \\
\hline L. chilense LA 1932 & $5 \mathrm{pg}$ & $1 \mathrm{pg}$ & $0.1 \mathrm{pg}$ & & & & \\
\hline PCR & - & + & +- & & & & \\
\hline Dot blot & +- & - & & & & & \\
\hline ELISA & - & - & & & & & \\
\hline
\end{tabular}

${ }^{a}$ Weight of fresh tissue corresponding with $5 \mu$ of EP2 extraction and one 1/5 (D1) and five 1/10 dilutions (D2 to D6).

${ }^{\mathrm{b}}$ Viral ssDNA in pg or ng, 30 DPI: days post cage whitefly-mediated inoculation, in 5- $\mu 1$ spots of EP2 extraction of each genotype estimated by using the calibration curve constructed with known amounts of purified TYLCV DNA. Data are means of six replicates.

${ }^{\mathrm{c}}$ Estimated viral ssDNA in serial dilutions.

$\mathrm{d}+=$ detected, $-=$ not detected, $+-=$ variable response. 
successfully used it only in preliminary monitoring of field advanced breeding lines because of its high dependence on the nature and the state of the tissue.

Hybridization procedures, although more complex, overcome serological limitations. These have a higher sensitivity, and unlike serological and nonradioactive hybridization methods (digoxigenin-labeled or chromogenic probes) $(1,7,37)$, detection with radioactive probes is less affected by background limitations, because it is less dependent on the origin and nature of the sample assayed.

The similar sensitivity found in squash blot and dot blot hybridization assays makes the simpler squash assay preferred as a preliminary test. The easy sampling method that can be conducted in the field by nonspecialized personnel makes this procedure the most appropriate to confirm TYLCV presence in samples with inconclusive results from TAS-ELISA when assaying field advanced breeding lines.

Dot blot is more informative than squash blot because it allows direct quantification of the virus by densitometric evaluations of the spots. However, the DNA extraction procedures, which are time-consuming, reduce the acceptance of dot blotting in large-scale analysis $(8,22)$. Simple extraction procedures requiring the minimum of purification steps (EP3 and EP4) detected TYLCV in dot blots and distinguished levels of resistance among genotypes. These procedures can be used to accelerate the treatment of samples by combining equal amounts of tissue from several plants, as they allow TYLCV detection in a minimal amount of tissue.
However, when testing highly resistant genotypes, which accumulate low viral concentrations, it is advisable to use a detection strategy based on dot blot, followed by PCR to confirm inconclusive results $(<1$ pg viral ssDNA).

The most sensitive PCR is adequate for early detection of TYLCV in young tissues (23). It also is suitable for testing young plantlets in seedbeds; by using small amounts of fresh tissue, thousands of plants can be rapidly tested in order to release virus-free plants. However, a disadvantage of this technique is the difficulty of obtaining high-quality purified preparations from field plants.

Our results provide the information necessary to establish a more adequate selection strategy at each stage of the breeding program by combining the advantages of each detection technique.

\section{ACKNOWLEDGMENTS}

The authors thank E. R. Bejarano (University of Malaga, Spain) for kindly providing the DNA TYLCV probe, and I. Hita and J. L. Cenis (CIDA, Murcia, Spain) for advice about the TAS-ELISA procedures and for kindly providing the specific primers for PCR amplification. This research was supported by the project PB-94-0530-C03-02 of the DGICYT program.

\section{LITERATURE CITED}

1. Abou Jawdah, Y., Shebaro, W. A., and Soubra, K. H. 1995. Detection of tomato yellow leaf curl geminivirus (TYLCV) by a digoxigenin-labelled DNA probe. Phytopathol. Mediterr. 34:52-57.

2. Abou Jawdah, Y., Soubra, K. H., and Shebaro, W. A. 1996. Evaluation of the reaction of tomato genotypes to tomato yellow leaf curl geminivirus infection in Lebanon. Phytopathol. Mediterr. 35:91-99.
3. Bedford, I. D., Kelly, A., Banks, G. K., Briddon, R. W., Cenis, J. L., and Markham, P. G. 1998. Solanum nigrum: An indigenous weed reservoir for a tomato yellow leaf curl geminivirus in southern Spain. Eur. J. Plant Pathol. 104:221-222.

4. Chague, V., Mercier, J. C., Guenard, M., de Courcel, A., and Vedel, F. 1996. Identification and mapping on chromosome 9 of RAPD markers linked to $\mathrm{Sw}-5$ in tomato by bulked segregant analysis. Theor. Appl. Genet. 92:1045-1051.

5. Chague, V., Mercier, J. C., Guenard, M., de Courcel, A., and Vedel, F. 1997. Identification of RAPDs markers linked to a locus involved in quantitative resistance to TYLCV in tomato by bulked segregant analysis. Theor. Appl. Genet. 95:671-677.

6. Chiang, B.-T., Nakhla, M. K., Maxwell, D. P., Schoenfelder, M., and Green, S. K. 1997. A new geminivirus associated with a leaf curl disease of tomato in Tanzania. Plant Dis. 81:111

7. Crespi, S., Accotto, G. P., Caciagli, P., and Gronenborn, B. 1991. Use of digoxigenin-labelled probes for detection and host-range studies of tomato yellow leaf curl geminivirus. Res. Virol. 142:283-288.

8. Czosnek, H., Ber, R., Navot, N., Zamir, D., Antignus, Y., and Cohen, S. 1988. Detection of tomato yellow leaf curl virus in lysates of plants and insects by hybridization with a viral DNA probe. Plant Dis. 72:949-951.

9. Czosnek, H., and Laterrot, H. 1997. A worldwide survey of tomato yellow leaf curl viruses. Arch. Virol. 142:1391-1406.

10. Dax, E., Livneh, O., Aliskevicius, E., Edelbaum, O., Kedar, N., Gavish, N., Milo, J. Geffen, F., Blumenthal, A., Rabinowich, H. D., and Sela, I. 1998. A SCAR marker linked to the ToMV resistance gene, $\mathrm{Tm} 2^{2}$, in tomato. Euphytica 101:73-77.

11. Dellaporta, S. L., Wood, J., and Hicks, H. B. 1983. A plant DNA minipreparation: Version II. Plant Mol. Biol. Rep. 14:19-21.

12. Di Martino, M. T., Albanese, G., Silvestro, I., and Catara, A. 1993. Rapid detection of to-
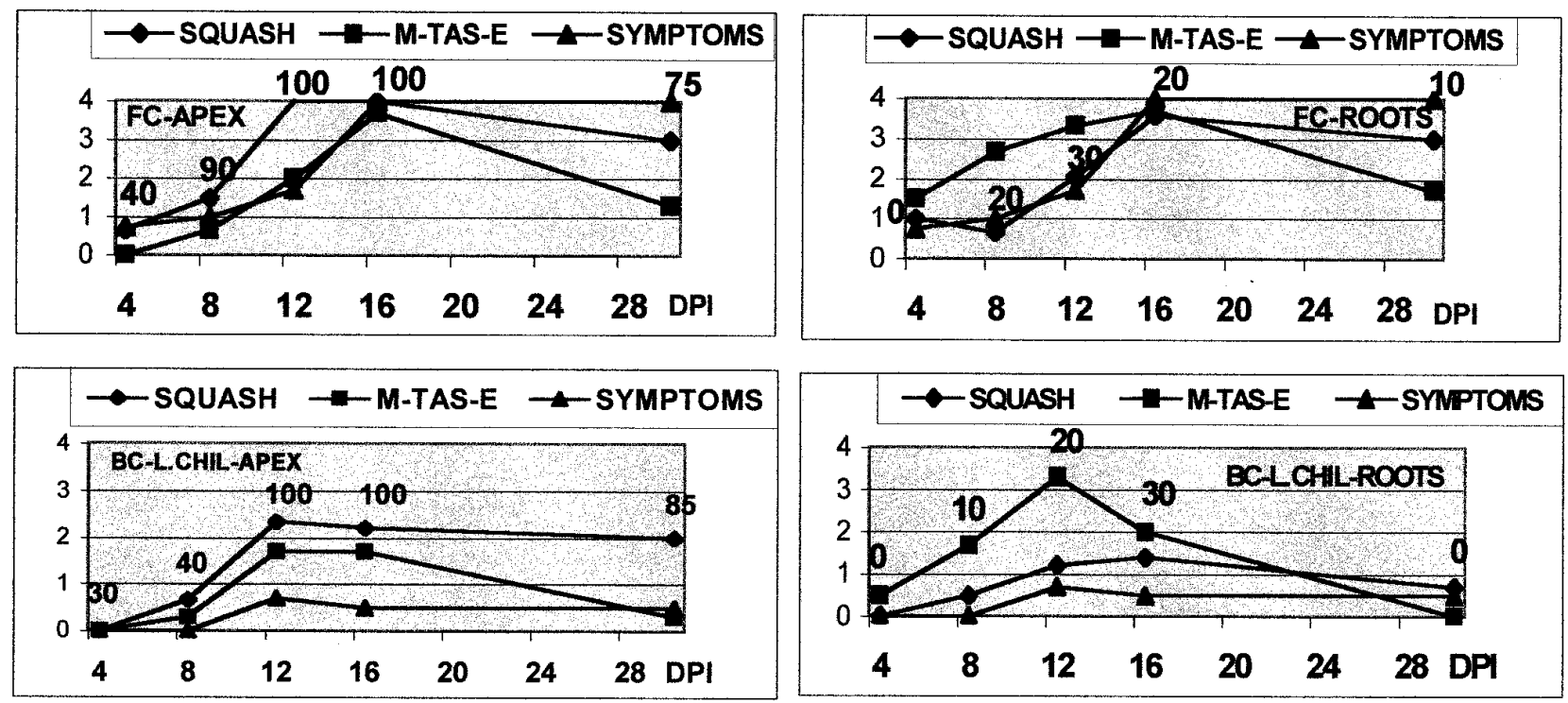

Fig. 2. Tomato yellow leaf curl geminivirus (TYLCV) accumulation detected by modified triple antibody sandwich-enzyme-linked immunosorbent assay (M-TAS-ELISA), polymerase chain reaction (PCR), and squash blotting in shoot apex and roots of tomato line FC and backcross BC2-chil several times after cage-whitefly artificial inoculation. Correlation with symptomatology. DPI: Days post cage whitefly-mediated inoculation. Symptoms: Mean scores of symptoms for each genotype: 0 (symptomless) to 4 (severe symptoms). M-TAS-ELISA: Absorbances $\left(A_{405 \mathrm{~nm}}\right)$ were recorded $24 \mathrm{~h}$ after addition of substrate and represent averages of four wells scored as follows: negative $=0$ ( $\leq$ twice the absorbance on the healthy control); 1 ( $>$ twice the healthy control but $\leq 0.6)$; 2 (>0.6 but $\leq 1.2) ; 3$ (>1.2 but $\leq 1.8)$; $4(>1.8)$. Squash blot: viral accumulation as estimated by scoring densitometric squash blot results ranging from 0 (no signal) to 4 (strong signal as the susceptible control). Numbers above data points are percentages of PCR-positive plants at each sampling date. 
mato yellow leaf curl virus in plants by polymerase chain reaction. Riv. Patol. Veg. 3:3540.

13. Fargette, D., Leslie, M., and Harrison, B. D. 1996. Serological studies on the accumulation and localization of three tomato leaf curl geminiviruses in resistant and susceptible $L y$ copersicon species and tomato cultivars. Ann. Appl. Biol. 128:317-328.

14. Givord, L., Fargette, D., Kounounguissa, B., Thouvenel, J. C., Walter, B., and Van Regenmortel, M. H. V. 1994. Detection of geminiviruses from tropical countries by a double monoclonal antibody ELISA using antibodies to African cassava mosaic virus. Agronomie 14:327-333.

15. Hajimorad, M. R., Kheyr-Pour, A., Alavi, V., Ahoonmanesh, A., Bahar, M., Rezaian, M. A., and Gronenborn, B. 1996. Identification of whitefly-transmitted tomato yellow leaf curl geminivirus from Iran and a survey of its distribution with molecular probes. Plant Pathol. 45:418-425.

16. Konate, G., Barro, N., Fargette, D., Swanson, M. M., and Harrison, B. D. 1995. Occurrence of whitefly-transmitted geminiviruses in crops in Burkina Faso, and their serological detection and differentiation. Ann. Appl. Biol. 126:121-129.

17. Lapidot, M., Friedmann, M., Lachman, O., Yehezkel, A., Nahon, S., Cohen, S., and Pilowsky, M. 1997. Comparison of resistance level to tomato yellow leaf curl virus among commercial cultivars and breeding lines. Plant Dis. 81:1425-1428.

18. Louro, D., Noris, E., Veratti, F., and Accotto, G. P. 1996. First report of tomato yellow leaf curl virus in Portugal. Plant Dis. 80:1079.

19. Macintosh, S., Robinson, D. J., and Harrison B. D. 1992. Detection of three whiteflytransmitted geminiviruses occurring in Europe by test with heterologous antibodies. Ann. Appl. Biol. 121:297-303.

20. Michelson, I., Zamir, D., and Czosnek, H. 1994. Accumulation and translocation of tomato yellow leaf curl virus (TYLCV) in a $L y$ copersicon esculentum breeding line containing the $L$. chilense TYLCV tolerance gene
Ty-1. Phytopathology 84:928-933.

21. Nakhla, M. K., Mazyad, H. M., and Maxwell, D. P. 1993. Molecular characterization of four tomato yellow leaf curl virus isolates from Egypt and development of diagnostic methods. Phytopathol. Mediterr. 32:163-173.

22. Navas-Castillo, J., Sanchez-Campos, S., Diaz, J. A., Saez-Alonso, E., and Moriones, E. 1998. First report of tomato yellow leaf curl virus-Is in Spain: Coexistence of two different geminiviruses in the same epidemic outbreak. Plant Dis. 81:1461.

23. Navot, N., Ber, R., and Czosnek, H. 1989. Rapid detection of tomato yellow leaf curl virus in squashes of plants and insect vectors. Phytopathology 79:562-568.

24. Navot, N., Zeidan, M., Pichersky, E., Zamir, D., and Czosnek, H. 1992. Use of the polymerase chain reaction to amplify tomato yellow leaf curl virus DNA from infected plants and viruliferous whiteflies. Phytopathology 82:1199-1202.

25. Noris, E., Accotto, G. P., and Luisoni, E. 1994. Advances in diagnosing tomato yellow leaf curl geminivirus infection. Mol. Biotechnol. 2:219-226.

26. Pico, B., Díez, M. J., and Nuez, F. 1996. Viral diseases causing the greatest economic losses to the tomato crop. II. The tomato yellow leaf curl virus-a review. Sci. Hortic. 67:151-196.

27. Pico, B., Díez, M. J., and Nuez, F. 1998. Evaluation of whitefly-mediated inoculation techniques to screen Lycopersicon esculentum and wild relatives for resistance to tomato yellow leaf curl virus. Euphytica 101:259271.

28. Pilowsky, M., and Cohen, S. 1990. Tolerance to tomato yellow leaf curl virus derived from Lycopersicon peruvianum. Plant Dis. 74:248250.

29. Rom, M., Antignus, Y., Gidoni, D., Pilowsky, M., and Cohen, S. 1993. Accumulation of tomato yellow leaf curl virus DNA in tolerant and susceptible tomato lines. Plant Dis. 77:253-257.

30. Shalaby, A. A., Nakhla, M. K., Shafie, M. S., Mazyad, H. M., and Maxwell, D. P. 1997.
Molecular characterization of tomato yellow leaf curl geminivirus (TYLCV) isolated from pepper collected in Egypt. Ann. Agric. Sci. 35:819-831.

31. Thomas, J. E., Massalski, P. R., and Harrison, B. D. 1986. Production of monoclonal antibodies to African cassava mosaic virus and differences in their reactivities with other whitefly-transmitted geminiviruses. J. Gen Virol. 67:2739-2748

32. Vidavsky, F., and Czosnek, H. 1998. Tomato breeding lines resistant and tolerant to tomato yellow leaf curl virus issued from Lycopersicon hirsutum. Phytopathology 88:910-914.

33. Vidavsky, F., Leviatov, S., Milo, J., Rabinowitch, H. D., Kedar, N., and Czosnek, H. 1998. Response of tolerant breeding lines of tomato Lycopersicon esculentum, originating from three different sources ( $L$. peruvianum, $L$. pimpinellifolium and $L$. chilense) to early controlled inoculation by tomato yellow leaf curl virus (TYLCV). Plant Breed. 117:165169.

34. Wyatt, S. D., and Brown, J. K. 1996. Detection of subgroup III geminivirus isolates in leaf extracts by degenerate primers and polymerase chain reaction. Phytopathology 86:1288-1293.

35. Zakay, Y., Navot, N., Zeidan, M., Kedar, N. Rabinowitch, H., Czosnek, H., and Zamir, D. 1991. Screening Lycopersicon accessions for resistance to tomato yellow leaf curl virus: Presence of viral DNA and symptom development. Plant Dis. 75:279-281.

36. Zamir, D., Ekstein-Michelson, I., Zakay, Y., Navot, N., Zeidan, M., Sarfatti, M., Eshed, Y. Harel, E., Pleben, T., Van-Oss, H., Kedar, N., Rabinowitch, H. D., and Czosnek, H. 1994. Mapping and introgression of a tomato yellow leaf curl virus tolerance gene, Ty-1. Theor. Appl. Genet. 88:141-146.

37. Zilberstein, A., Navot, N., Ovadia, S., Reinhartz, A., Herzberg, M., and Czosnek, H 1989. Field-usable assay for diagnosis of the tomato yellow leaf curl virus in squashes of plants and insects by hybridization with a chromogenic DNA probe. Technique 1:118124. 